\title{
TRANSFORMASI PLASMID YANG MENGANDUNG GEN merB PADA Escherichia coli BL21(DE3)
}

\author{
Zefanya G. Bernadus ${ }^{1)}$, Fatimawali ${ }^{1)}$, Beivy Kolondam ${ }^{2)}$ \\ ${ }^{1)}$ Program Studi Farmasi FMIPA UNSRAT Manado, 95115 \\ 2) Jurusan Biologi FMIPA UNSRAT Manado, 95115
}

\begin{abstract}
DNA transformation is one of the methods for inserting DNA into bacterial cells. The current transformation method is widely used to transfer plasmids containing genetic material. This study aims to evaluate the results of plasmid transformation containing merB gene in Escherichia coli BL21(DE3) bacteria. The stages of the research carried out were preceded by the microbiological identification of the E. coli BL21(DE3) bacteria used as hosts. Then the plasmid transformation containing merB gene into the E. coli BL21(DE3) host cell using the heat shock method was carried out. The transformation results were evaluated by observing at the presence of E. coli BL21(DE3) colonies on agar Luria Bertani (LB) media containing ampicillin antibiotics. Plasmids in E. coli BL21(DE3) were isolated and analyzed by $1 \%$ agarose gel electrophoresis. The results showed the success of the transformation indicated by the growth of E. coli BL21(DE3) bacteria in agar LB media containing ampicillin and the visualization on agarose gel resulted that the plasmid which carried the merB gene could be transformed in to the E. coli BL21(DE3) bacteria.
\end{abstract}

Keywords : Plasmids, merB genes, heat shock, Escherichia coli BL21(DE3)

\begin{abstract}
ABSTRAK
Transformasi DNA merupakan salah satu metode untuk memasukkan DNA ke dalam sel bakteri. Metode transformasi saat ini dipakai secara luas untuk mentransfer plasmid yang mengandung bahan genetika. Penelitian ini bertujuan untuk mengevaluasi hasil transformasi plasmid yang mengandung gen merB pada bakteri Escherichia coli BL21(DE3). Tahapan penelitian didahului dengan identifikasi secara mikrobiologi bakteri E. coli BL21(DE3) yang digunakan sebagai inang. Selanjutnya dilakukan transformasi plasmid yang mengandung gen merB kedalam sel inang E. coli BL21(DE3) menggunakan metode heat shock. Hasil transformasi dievaluasi dengan melihat adanya koloni E. coli BL21(DE3) pada media agar Luria Bertani (LB) yang mengandung antibiotik ampisilin. Plasmid pada E. coli BL21(DE3) diisolasi dan dianalisis dengan elektroforesis gel agarose $1 \%$. Hasil penelitian menunjukkan keberhasilan transformasi dengan adanya pertumbuhan bakteri E. coli BL21(DE3) pada media LB yang mengandung ampisillin dan hasil visualisasi pada agarose gel terlihat bahwa plasmid yang membawa gen merB dapat ditransformasikan ke dalam bakteri E. coli BL21(DE3).
\end{abstract}

Kata Kunci : Plasmid, gen merB, heat shock, Escherichia coli BL21(DE3) 


\section{PENDAHULUAN}

Pencemaran lingkungan akibat merkuri menjadi permasalahan serius di seluruh dunia (Wang et al., 2012). Sumber pencemaran merkuri dapat berasal dari aktivitas manusia seperti pembakaran batubara, jenis-jenis produk minyak bumi, penggunaan fungisida, katalisator merkuri dan penambangan emas yang menggunakan merkuri sebagai bahan pengekstraksi emas (Fatimawali, 2011).

Penambangan emas rakyat saat ini masih menjadi salah satu kegiatan ekonomi masyarakat Sulawesi Utara. Aktivitas penambangan ini menghasilkan produk limbah yang banyak mengandung logamlogam berat sehingga berpotensi mencemari lingkungan dan juga membahayakan kesehatan karena adanya efek toksik. Produk limbah ini dihasilkan dari sisa pengolahan emas dan salah satunya adalah merkuri (Bapedalda Sulut, 2002). Mengingat berbagai dampak akibat pencemaran merkuri ini maka perlu dipikirkan cara untuk mengubah atau menurunkan kadar merkuri.

Berdasarkan beberapa penelitian dilaporkan adanya penguraian senyawa merkuri oleh bakteri yang menghasilkan perubahan bentuk merkuri di lingkungan. Umumnya bakteri ini ditemukan pada area kadar merkuri yang tinggi (Nelson et al, 1972). Hal ini menunjukkan bahwa bakteri yang berada di daerah tercemar merkuri dapat menjadi sumber isolasi bakteri resisten merkuri. Detoksifikasi oleh bakteri resisten merkuri dilakukan secara enzimatis. Hal ini dapat terjadi karena bakteri resisten merkuri memiliki operon merkuri resisten (mer). Saat ini diketahui ada beberapa jenis bakteri resisten merkuri diantaranya gen merB yang mengkode organomerkuri liase yang mengkatalisis pemutusan ikatan merkurikarbon sehingga menghasilkan senyawa organik dan ion $\mathrm{Hg}^{2+}$, kemudian gen merA mengkode merkuri reduktase menjadi $\mathrm{H}^{0}$ yang sifatnya kurang toksik (Das dan Dash, 2015; Rojas et al., 2011). Penggunaan gen ini dalam detoksifikasi perlu diproses lagi sehingga detoksifikasi dapat dilakukan oleh protein, namun sebelum itu diperlukan tahap transformasi sebelum dilakukan overproduksi untuk menghasilkan protein tersebut.

Kloning dilakukan dalam upaya seleksi dan pemurnian suatu gen dalam jumlah besar dan yang bebas dari kontaminasi oleh urutan DNA lain. Salah satu tahapan yang harus dilakukan dalam kloning gen adalah transformasi. Langkah awal pada kloning gen yakni fragmen DNA yang mengandung gen yang akan kloning diinsersi ke dalam vector. Vektor ini dapat menjadi media pengantar kepada host cell (Brown, 2010). Metode transformasi yang paling sering digunakan adalah metode heat shock yang umumnya dilakukan pada suhu $42^{\circ} \mathrm{C}$ selama 2 menit. Prinsip metode ini yaitu kejutan suhu tinggi selama beberapa detik pada sel bakteri sehingga plasmid dapat masuk ke dalam sel (Sambrook dan Russel, 2001). Hasil transformasi ini dapat dipengaruhi oleh waktu dan suhu heat shock. Oleh karena itu pada beberapa penelitian sebelumnya dilakukan transformasi dengan variasi waktu dan suhu untuk melihat efektivitas transformasi plasmid ke dalam sel inang.

Adapun penelitian serupa dengan penelitian ini yang telah dilakukan sebelumnya oleh Fatimawali (2017), di mana detoksifikasi merkuri secara enzimatik dengan merkuri reduktase merA (merkuri reduktase). Merkuri reduktase digunakan untuk detoksifikasi merkuri anorganik, sedangkan gen mer B (organomerkuri liase) digunakan untuk detoksifikasi merkuri organik yakni dengan pemutusan ikatan merkuri-karbon. Untuk itu penelitian ini dilakukan dengan tujuan untuk melihat apakah plasmid yang 
mengandung gen mer $\mathrm{B}$ dapat di transformasi pada bakteri E. coli BL21(DE3).

\section{METODOLOGI PENELITIAN}

\section{Alat dan Bahan}

Alat

Alat yang digunakan dalam penelitian yaitu cawan petri, lampu bunsen, tip, sentrifuge tube, tabung microsentrifuge (eppendorf), Incubator Shaker, labu Erlenmeyer, timbangan analitik, jarum ose, inkubator (Incucell), laminar air flow (Biotek), autoklaf (ALP), hot plate, mikropipet (Ecopipette), kertas label, plastik wrap, aluminium foil, kapas, kasa, elektroforesis (Biometra T-Personal), UV transluminator dan alat fotografi.

\section{Bahan}

Bahan yang digunakan dalam penelitian yaitu Aquabidest/ ddH2O, Alkohol, NaCl, Tripthon, Yeast, Agar bakteriological, Ethidium Bromide (EtBr), TSS (Polyethylene Glicol (PEG), Dimethyl sulfoxide (DMSO), Luria Bertani (LB) dan $\mathrm{MgCl} 2$ ), Antibiotik ampicilin, Agarose, TAE, kit isolasi DNA bakteri (Geneaid), loading dye, dan spiritus.

\section{Transformasi plasmid yang mengandung gen merB}

Prosedur transformasi dilakukan sesuai dengan Fatimawali et al., (2017) dengan modifikasi. Plasmid yang mengandung gen merB di transformasikan pada E. coli BL21(DE3) yaitu $5 \mu \mathrm{L}$ larutan plasmid dipipet kedalam E. coli BL21(DE3) $200 \mu$ L. Langkah ini dilakukan pada 3 falcon yang berbeda untuk variasi suhu pada heat shock. Langkah selanjutnya diinkubasi pada suhu $0^{0} \mathrm{C}$ (es) selama 30 menit, kemudian di heat shock dengan inkubasi pada thermo block dengan variasi suhu (1) $40^{\circ} \mathrm{C}$, (2) $42^{\circ} \mathrm{C}$, (3) $44^{\circ} \mathrm{C}$ masing-masing dilakukan selama 30 detik. Setelah itu diinkubasi lagi pada es selama 10 menit, ditambahkan $800 \mu \mathrm{L}$ media LB cair. Selanjutnya disentrifuge $3.670 \mathrm{rpm}$ selama 10 menit dan sebanyak $800 \mu \mathrm{L}$ supernatan dibuang sehingga tersisa $200 \mu \mathrm{L}$. Dipipet masing-masing sebanyak $200 \mu \mathrm{L}$ dan di spread pada media LB agar yang mengandung ampicilin $(100 \mu \mathrm{L} / \mathrm{ml})$ kemudian diinkubasi selama 18 jam pada suhu $37^{\circ} \mathrm{C}$. Disamping itu dibuat juga kontrol untuk membandingkan pertumbuhannya, dipipet sebanyak $200 \mu \mathrm{L}$ hasil kultur E. coli BL21(DE3) dan di spread pada media LB agar yang mengandung ampicilin $(100 \mu \mathrm{L} / \mathrm{ml})$ kemudian diinkubasi seperti hasil transformasi yaitu selama 18 jam pada suhu $37^{0} \mathrm{C}$. Transformasi dikatakan berhasil bila adanya pertumbuhan pada media yang engandung ampicillin dan bila terlihat pita DNA dengan ukuran 639 bp yaitu sesuai dengan ukuran gen merB yang telah diinsersikan pada plasmid.

\section{Isolasi plasmid}

Isolasi DNA plasmid dilakukan dengan menggunakan PrestoTM Mini Plasmid Kit (Geneaid).

Elektroforesis hasil transfomasi plasmid yang mengandung gen merB dan Visualisasi UV

Prosedur elektroforesis dilakukan sesuai dengan Langden et al., (2017) dengan modifikasi. Agarose $1 \%$ disiapkan yaitu sebanyak $0,4 \mathrm{~g}$ dan dicampur dengan TAE $1 \%$ sebanyak $40 \mathrm{ml}$ kemudian dipanaskan di hot plate hingga mendidih. Sisir dipasang pada cetakan gel, kemudian dituang agar dan ditunggu hingga dingin dan memadat. Sampel ditambahkan $1 \mu \mathrm{L}$ loading dye kemudian dimasukkan ke sumuran gel. Ladder (marker) juga di masukkan ke sumuran gel di sisi sampel. Elektroforesis dilakukan selama 50 menit. Hasil elektroforesis direndam selama 
10 menit di dalam EtBr yang harus dilakukan dengan hati-hati dan sebaiknya di lakukan diruang asam. Setelah itu hasil elektroforesis divisualisasi dengan UV transluminator.

\section{HASIL DAN PEMBAHASAN \\ Pembuatan Sel Kompeten}

Sebelum di transformasi, sel bakteri $E$. coli BL21(DE3) dibuat menjadi sel kompeten terlebih dahulu. Tahap pembuatan sel menjadi kompeten merupakan langkah penting dalam proses transformasi (Silitonga, 2016). Untuk itu bakteri di subkultur selama 90 menit pada incubator shaker kemudian di cek nilai optical density pada panjang gelombang 600 $\mathrm{nm}\left(\mathrm{OD}_{600}\right) . \mathrm{OD}_{600}$ sering digunakan untuk mengukur pertumbuhan sel di mana pada nilai ini sel bakteri tidak akan mati meski terkena cahaya sinar UV yang terlalu banyak. Sel kompeten yang paling baik memiliki nilai $\mathrm{OD}_{600}(0,3-0,4)$ yaitu pada awal fase eksponensial (Chung, 1989) atau disebut juga periode steady state (Sezonov, 2007). Nilai $\mathrm{OD}_{600}$ pada penelitian ini dapat dilihat pada tabel 2.

Tabel 2. Nilai absorbansi sel kompeten (1) $40^{\circ} \mathrm{C}$, (2) $42^{\circ} \mathrm{C}$, (3) $44^{\circ} \mathrm{C}$

\begin{tabular}{ccc}
\hline Nilai OD $_{600}$ & Nilai OD $_{600}$ & Nilai OD \\
$(\mathbf{1})$ & $(\mathbf{2})$ & $(\mathbf{3})$ \\
\hline 0,38 & & \\
\hline
\end{tabular}

Selanjutnya sel bakteri disentrifugasi kemudian peletnya ditambahkan TSS. TSS terdiri dari Polyethylene Glicol (PEG), Dimethyl sulfoxide (DMSO), Luria Bertani (LB) dan $\mathrm{MgCl}$ 2. Penambahan TSS dilakukan agar sel menjadi kompeten. Selain itu penambahan unsur garam dapat membuat lebih efisien dalam transformasi (Liu et al., 2014). Dengan adanya kation bivalen $\mathrm{Mg}^{2+}$, fusi membran akan meningkat sehingga akan mempercepat interaksi DNA dengan permukaan E. coli (Sato et al., 2005).

\section{Transformasi}

Pada penelitian ini transformasi menggunakan metode heat shock dilakukan pada beberapa suhu untuk melihat suhu yang paling optimal untuk transformasi. Suhu heat shock mempengaruhi efisiensi transformasi (Inoue, 1990). Tahapan heat shock merupakan salah satu hal yang mempengaruhi keberhasilan transformasi. Dengan metode ini dapat membuat DNA mampu melewati dinding sel inang (Li et al., 2010). Hasil transformasi plasmid yang mengandung gen merB pada E. coli BL21(DE3) dengan 3 variasi suhu heat shock (1) $40^{\circ} \mathrm{C}$, (2) $42^{\circ} \mathrm{C}$, (3) $44^{\circ} \mathrm{C}$ ditumbuhkan masing-masing pada media LB (Luria Bertani) agar yang diberikan antibiotik kemudian diinkubasi. Hal ini dilakukan untuk melihat keberhasilan hasil transformasi yaitu dengan seleksi antibiotik (Jang dan Magnuson, 2013). Begitupun kontrol yang digunakan pada penelitian ini yakni E. coli BL21(DE3) yang belum ditansformasi (sel inang) ditumbuhkan juga pada media yang mengandung antibiotik. Hasil penelitian ini menunjukkan bahwa transformasi plasmid berhasil dilakukan karena E. coli BL21(DE3) rekombinan tumbuh pada media yang diberikan ampicillin (Gambar 4) sedangkan E. coli BL21(DE3) 
tidak tumbuh (Gambar 5). Hal ini dapat terjadi karena bakteri E. coli BL21(DE3) rekombinan telah mengandung plasmid yang membawa sifat resisten terhadap antibiotik dan jenis plasmid yang digunakan pada penelitian ini resisten terhadap antibiotik jenis ampicilin sehingga bakteri E. coli BL21(DE3) rekombinan hanya akan tumbuh pada media yang diberikan ampicillin $(100 \mu \mathrm{L} / \mathrm{ml})($ Casali dan Preston, 2003). Media yang digunakan pada penelitian ini adalah LB yang terdiri dari Trypthon, Yeast extract, $\mathrm{NaCl}$ dan air. Media ini sangat sering digunakan karena memungkinkan pertumbuhan yang cepat dan hasil pertumbuhannya baik untuk banyak spesies (Sesonov et al, 2007).
(1)
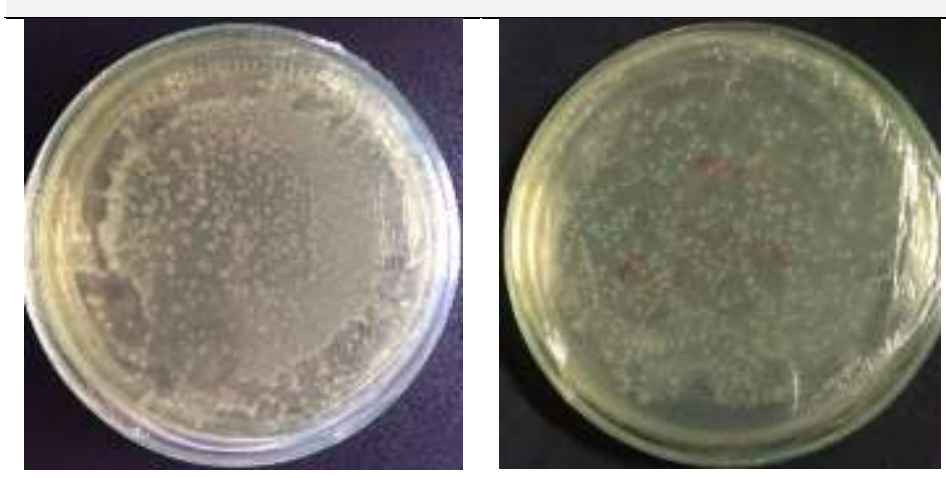

(3)

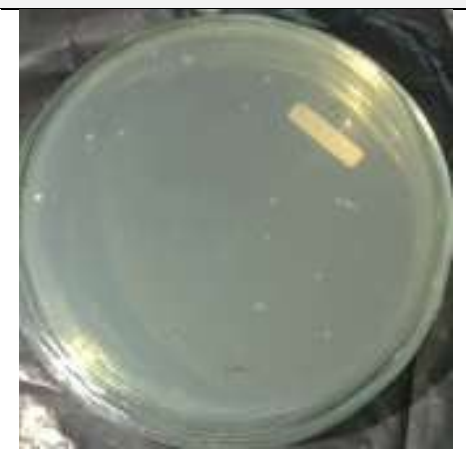

Gambar 4. E. coli BL21(DE3) rekombinan setelah diinkubasi;

Keterangan : transformasi dengan suhu heat shock (1) $40^{\circ} \mathrm{C}$, (2) $42^{\circ} \mathrm{C}$, (3) $44^{\circ} \mathrm{C}$

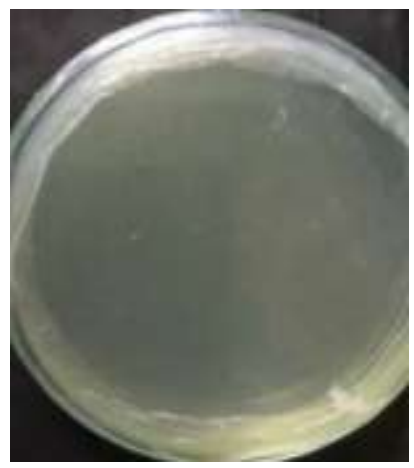

Gambar 5. E. coli BL21(DE3) setelah diinkubasi (Kontrol)

Metode heat shock adalah metode transformasi yang paling sering digunakan. Prinsip metode ini yakni heat shock (kejutan panas) selama beberapa waktu sehingga plasmid dapat masuk kedalam sel inang (Sambrook dan Russel, 2001). Heat shock mengubah struktur membran bakteri sehingga membantu DNA masuk ke dalam sel dengan cepat.
Pada penelitian sebelumnya transfomasi plasmid pTA7002-AtRKD4 pada E. coli BL21(DE3) berhasil dilakukan pada suhu heat shock $44^{\circ} \mathrm{C}$ selama 30 detik (Tanio, 2017). Selain itu adapun penelitian lain yang menyatakan transformasi yang efisien pada suhu $42^{\circ} \mathrm{C}$ selama 30 detik (Singh, 2010). Oleh karena itu dapat dilihat bahwa belum ada suhu pada saat heat shock yang optimum untuk transformasi. 
Pada penelitian ini dapat dilihat bahwa perlakuan transformasi dengan metode heat shock berhasil dilakukan pada 3 variasi suhu heat shock (1) $40^{\circ} \mathrm{C}$, (2) $42^{\circ} \mathrm{C}$, (3) $44^{0} \mathrm{C}$. Meskipun demikian, efisiensi transformasi tidak hanya dipengaruhi pada suhu heat shock, melainkan ada juga faktorfaktor lain seperti ukuran plasmid, bentuk plasmid yang digunakan, dan juga jenis larutan garam pada saat pembuatan sel kompeten yang akan menjadi sel inang (Liu et al, 2014).

\section{Isolasi Plasmid}

Pada penelitian ini dilakukan isolasi plasmid menggunakan Genomic DNA Mini Kit (Geneaid). Pada prinsipnya isolasi plasmid ini dilakukan untuk memisahkan DNA dari protein dan RNA dan memisahkan DNA plasmid dari DNA kromosom.

\section{Elektroforesis hasil transfomasi plasmid dan Visualisasi UV}

Hasil isolasi plasmid dilanjutkan dengan uji konfirmasi yaitu dengan elektroforesis gel agarose $1 \%$ kemudian di visualisasi UV. Visualisasi gel agarosa dilakukan menggunakan $U V$ transillluminator. Visualisasi UV hasil transformasi dapat dilihat pada Gambar 6 . Hasil elektroforesis ini terlihat dengan munculnya pita (band) DNA yang berada pada ukuran antara 600 bp dan 700 bp. Ukuran gen merB adalah 639 bp (Fatimawali, komunikasi pribadi). Hal ini membuktikan bahwa transformasi plasmid berhasil dilakukan pada bakteri E. coli BL21(DE3).

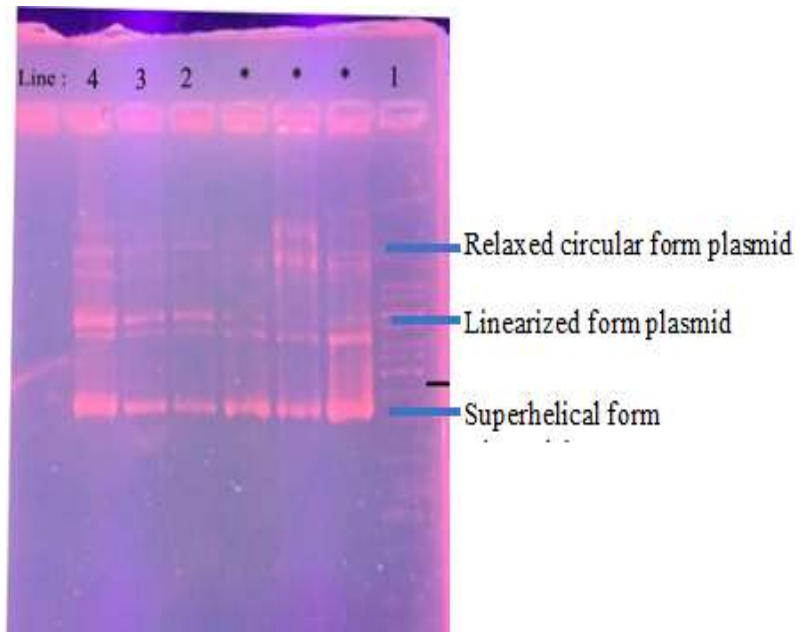

Gambar 6. Electrophoregram hasil

transformasi plasmid: Line 1 : marker; Line 2 : E.coli BL21 (DE3) rekombinan (1) $40^{\circ} \mathrm{C}$; Line 3 : E.coli BL21 (DE3) rekombinan (2) $42^{0} \mathrm{C}$; Line 4 : E.coli BL21 (DE3) rekombinan $44^{0} \mathrm{C}$; Line $*$ : E.coli TOP10

\section{KESIMPULAN}

Berdasarkan hasil penelitian, dapat disimpulkan bahwa gen merB dapat ditransformasikan kedalam sel inang Escherichia coli BL21(DE3), sehingga dapat menjadi dasar untuk penelitian selanjutnya pada proses detoksifikasi merkuri organik menggunakan enzim merB.

\section{DAFTAR PUSTAKA}

Bapedalda Sulut, 2002. Penelitian Tentang Limbah Merkuri di Propinsi Sulawesi Utara Selang 2002 sampai 2001. Sub.Bidang Pengendalian Pencemar Air, Bapedalda, Manado

Brown, T. A. 2010. Gene cloning and DNA analysis. Blackwell Publishing, Oxford.

Casali, N. dan Preston, A. 2003. E. coli plasmid vectors: methods and applications. Humana Press, New Jersey.

Chung, C., Suzanne, L., Niemela., dan Miller, R. 1989. One-step preparation of 
competent Escherichia coli: Transformation and storage of bacterial cells in the same solution (recombinant DNA). Biochemistry (86): 2172-2175.

Das, S. dan Dash, H. R. 2015. Microbial biotechnology - a laboratory manual for bacterial systems. Springer, New Delhi.

Fatimawali., Kepel, B., dan Tallei, T. 2017. Overproduction of mercuric reductase protein expressed by synthetic merA gene and reduction of inorganic mercury $\mathrm{HgCl}$. Bioscience Research. (4)14: 1253-1260.

Fatimawali, F., Badaruddin, F., Yusuf, I. 2011. Isolasi dan identifikasi bakteri resisten merkuri dari muara Sungai Sario yang dapat digunakan untuk detoksifikasi limbah merkuri. Jurnal Ilmiah Sains. (2)11, 282-288.

Inoue, H., Nojima, H., Okayama, H. 1990. High efficiency transformation of Escherichia coli with plasmids. Gene 96. (1) : 23- 28.

Jang, C dan Magnuson, T. 2013. A Novel Selection Marker for Efficient DNA Cloning and Recombineering in E. coli. PLOS ONE. (2)8 :1-7.

Liu, X., Liu, L., Wang, Y., Wang, X, Ma, Y., dan Li, Y. 2014. The study on the factors affecting transformation efficiency of Escherichia coli competent cells. Pakistan journal of pharmaceutical sciences (3)27 : 679684.

Langden, S., Budiharjo, A., Wijanarka., dan Kusharyoto, W. 2017. Transformasi Dan Kloning Plasmid Pj804:77539 Pada E. coli Top'10. Jurnal Biologi. (1)6: 6570
Nelson., J., Blair, W., Brinckman, F., Collwel, R., Iverson, W. 1973. Biodegradation of Phenylmercuric Acetate by MercuryResistant Bacteria. Applied Microbiology. (26)3 : 321-326

Rojas, L.A., Yanez, C., Gonzalez, M., Lobos, S., Smalla, K. dan Seeger, M. 2011. Characterization of the metabolically modified heavy metal-resistant Cupriavidus metallidurans strains MSR33 generated for mercury bioremediation. PLOS ONE, 6: 1-1

Sambrook, J dan Russel, I., 2001. Molecular Cloning, A Laboratory Manual, Third Edition, Volume 2. Cold Spring Harbor Laboratory Press, New York.

Sezonov, G., Joseleau, D dan D'Ari, R. 2007. Escherichia coli Physiology in LuriaBertani Broth. Journal of Bacteriology. (189)23: 8746-8749

Sato, Y., Kumazawa, N., Yoshikawa, K., dan Kurusu, Y. 2005. Transformation of Escherichia coli Mediated by Natural Phospholipids.

Silitonga, Y. 2016. Resistensi Cronobacter Sakazakii Terhadap Ampisilin dan Hubungannya dengan Stabilitas dan Ekspresi Gfpuv [tesis]. Sekolah Pascasarjana IPB, Bogor.

Tanio, E. 2017. Efisiensi transformasi plasmid pTa7002-AtRKD4 pada Escherichia coli BL21(DE3) dengan metode kejutan panas [skrpisi]. Universitas Atmajaya, Yogyakarta.

Wang, J., Feng, X., Anderson, C., Xing, Y., Shang, L. 2012. Remediation of mercury contaminated sites - A review. Journal of Hazardous Materials. (221222): $1-18$ 